\title{
Application Progress of Nano Silver Dressing in the Treatment of Diabetic Foot
}

\author{
Huijing Lin ${ }^{1} *$ \\ Alayi BoLatai ${ }^{2, *}$ \\ $\mathrm{Na} \mathrm{Wu}{ }^{1,3}$ \\ 'Department of Endocrinology, Shengjing \\ Hospital of China Medical University, \\ Shenyang, Liaoning Province, People' \\ s Republic of China; ${ }^{2}$ Student Affairs \\ Department, Shengjing Hospital of China \\ Medical University, Shenyang, Liaoning \\ Province, People's Republic of China; \\ ${ }^{3}$ Clinical Skills Practice Teaching Center, \\ Shengjing Hospital of China Medical \\ University, Shenyang, Liaoning Province, \\ People's Republic of China
}

*These authors contributed equally to this work

Correspondence: $\mathrm{Na} \mathrm{Wu}$

Department of Endocrinology, Clinical

Skills Practice Teaching Center, Shengjing

Hospital of China Medical University,

Shenyang, I 10004, People's Republic of

China

Email 344I535223@qq.com

\begin{abstract}
Diabetic foot is a serious infection of the lower limbs. It is caused by diabetic neuropathy and vascular disease. It is also the primary cause of disability and death in patients with severe diabetes, so prompt treatment is essential for positive outcomes. The clinical use of nano-silver dressings can be considered to further optimize the treatment process and improve the treatment efficacy in diabetic foot patients. Nano-silver dressings have a larger contact surface and a stronger bactericidal effect when compared to ordinary silver dressings. Besides, it can be disinfected repeatedly to better wound infection control and promote wound healing. The current article discusses the pathogenesis of diabetic foot, diabetic foot dressing treatment, the application of nanotechnology in diabetic foot treatment, the efficacy evaluation of different dressings, and the practical prospects of adopting nanotechnology in the treatment of diabetic foot.
\end{abstract}

Keywords: nano-silver, diabetic foot, antibacterial dressings

\section{Introduction}

Diabetic foot is a common condition caused by foot ulcers, infections, or deep tissue damage, and is associated with distal nerve abnormalities and varying degrees of peripheral vascular lesions in the lower limbs. Nearly $15 \%$ of diabetes patients are at risk of developing foot ulcers as their disease progresses. ${ }^{1}$ According to reports, one person with diabetes in the world has a diabetic foot amputation every 20 seconds, with figures indicating rising annual mortality rates of $11 \%$ and $22 \%$, respectively. According to Studies, diabetic foot accounts for nearly one-third of the all diabetes-related medical costs. ${ }^{2}$ In compared to other complications, the evidence shows that the incidence, mortality, disability, and expenditure of diabetic foot in diabetes patients are high. Furthermore, because some diabetes patients do not have a typical inflammatory response to an infection, the signs of infection in diabetic patients are sometimes masked. Moreover, diabetic foot infection is often severe due to the accumulation of shallow and deep tissue, and even accumulated bones. ${ }^{2}$ As a result, the symptoms of diabetic foot patients are only noticed after the condition has worsens. As a consequence, diabetic foot often requires a combination of medical and surgical treatment. In particular, surgical dressing change and dressing application play a crucial role in wound treatment. Surgical dressings provide a wet wound environment, handle excess exudate, facilitate drainage, reduces contact with the wound to a certain extent, reduces the aggravation of infection or existing infection, helps in debridement, and promotes healing. Thus, in addition to requiring standardized medical and surgical treatment, good dressings for adjuvant treatment are critical. Nano-silver has been used in a different field as a class of 
antibacterial materials. It plays an important role in the treatment of diabetic foot. Nanotechnology is used to make nanosilver dressings. In addition to serving the corresponding role of traditional dressings, nano-silver dressings have specific antibacterial effects, and the antibacterial effect is efficient, wide spectrum, difficult to form drug resistance, safe, reliable, etc. $^{3}$ The present study summarizes the traditional treatment of diabetic foot and compares the application of different dressings in the treatment of diabetic foot by analyzing the pathogenesis of diabetic foot and the application of nano-silver dressing in diabetic foot.

\section{Diabetic Foot}

\section{Mechanism of the Diabetic Foot}

Due to the occurrence of developmental diabetes, the patient continues to eat unhealthy foods and engage inappropriate lifestyle habits, and he or she does not receive appropriate treatment. Therefore, the disease is unable to be controlled for a long period of time, and the blood sugar levels are higher than normal. Diabetes is worsening, and blood flow at the ends of the lower extremities failing to circulate normally due to blood vessels traumas and injuries of. Diabetic foot, the most serious complication of diabetes, develops eventually. The mechanism of diabetic foot is complicated. It can be caused by a genetic factor, slower limb neuropathy, vascular disease, or abnormal foot pressure. Foot infection factors are often secondary to nerve and vascular disease. ${ }^{4}$ In addition, a diabetic patients' bodies produce far more reactive oxygen species than is normal, throwing oxidation and anti-oxidation are out of balance, increasing oxidative stress and aggravating damage to blood vessels and nerves. ${ }^{5}$ Foot pressure is also a risk factor which is strongly related to the development of diabetic feet. Long-term mechanical pressure acts on the feet, and the continuous pressure action destroys the local tissues of the lower limbs, eventually resulting in sterile enzymatic autolysis. ${ }^{6}$ Genetic factors also play a certain role in the formation of diabetic foot, which is mainly manifested by voltage-gated potassium channel gene (KCNQ1), epigenetic factors such as methylation, etc. $^{3}$ These factors develop as a result of hyperglycemia. Vascular and neuropathy are the key factors, whereas foot pressure is the trigger. Eventually, the infection aggravates the pathology. ${ }^{7}$ The aforementioned factors work together to produce severe, difficult-to-cure, easily-infected diabetic foots with a high incidence.

\section{Dressing Treatment for Diabetic Foot}

In general, diabetic foot treatment is based on the control of blood sugar, condition judgment, the treatment based on the development of the specific condition, and treatment of the corresponding diseased tissue. The dressing plays a role in vascular disease and neurological dysfunction in general. The treatment of dressings is key in the treatment of diabetic foot because it is based on the control and removal of infectious bacteria as well asthe prevention of the invasion of other pathogens. In general clinical practice, dressing treatment is divided into two parts: evaluation and specific treatment after evaluation.

Diabetic foot wounds needs to be classified according to their appearance based on the development process of the condition in order to be evaluated. According to the general classification system, diabetic foot creation is divided into four stages: namely black (necrosis), yellow (inflammatory exudate), red (granulation formation), and pink (epithelial formation). ${ }^{8}$ Wound evaluation and judgment are based on the specific characteristics of each stage of diabetes foot. Following that, effective and corresponding measures are taken to treat the wound accordance to the different disease development stages. Specific measures include debridement treatment, dressing replacement, negative pressure drainage, dressing application, etc. Under controlled blood sugar, metabolism, and infection, palliative debridement to remove necrotic tissue can reduce the risk of infection. ${ }^{9}$ Debridement should be complete without leaving any necrotic tissue, and the range of debridement should not be excessive. In general, loose deep boils can form in the area around the swelling. ${ }^{10}$ In such instances, the skin at the wound's edge grows internally and shrinks, and the clear wiring around the wound is visible. Moreover, the granulation tissue inside the wound grows, secretions are reduced, and the wound protection field is formed. When necessary, effective sutures can reduce granulation filling time, accelerate wound healing, and reduced treatment costs. When changing drugs, disinfection and drug change frequency need to be considered. Changing medications can help to reduce the occurrence of infections to an extent. ${ }^{9}$ Adding anti-infection medication to the wound along with other oral drugs can significantly improve wound healing in diabetic foot. Drugs such as alkali hydrochloride combined with gentamicin, moist burn cream, can inhibit the growth of bacteria and weaken bacteria to promote recovery of diabetic foot. $^{11,12}$ Amoxicillin clavulanate potassium, levofloxacin, clinthromycin, cephalosporexin, and other anti-infection drugs are suitable for treating the methicillin-sensitive of 
Staphylococcus aureus infections. In severe cases, meropenem and other antibiotics can also be used. Patients treated at many hospitals are more likely to have a resistant strain of Staphylococcus aureus infection, in which case do oxycycline can be used, and severe cases can be treated with vancomycin and other anti-infection treatments. ${ }^{13}$ Antibiotics cannot be changed if the empirical treatment of antibiotics is good. Some new antibiotics also have certain effects on diabetic foot treatment, such as linezolid and Ertapenem. ${ }^{14}$

After a certain degree of evaluation for patients with diabetic foot, the following adjuvant treatment is the key to the entire treatment. To begin, it is important to choose a suitable dressing cover wound that can achieve sterilization drainage and maintain wound humidity whilst also protecting the wound. Some traditional fabrics such as sterile gauze and Vaseline gauze are being gradually replaced by other dressings. Recently, novel forms of dressing are increasingly used to treat diabetic foot, for example, some wet dressings such as hydrogel dressing, alginate dressing, bubble dressing, silver ion dressing, etc have shown promising results. Such dressings increase the healing rate considerably. ${ }^{8}$ Among these, silver ion has shown decent efficiency as a traditional antibacterial microbial preparation. The complex formed by the combination of foam dressing plays a specific role in antibacterial and leachate treatment. The underlying principle is to bind with bacteria DNA, making it difficult to bind with human DNA. Drug resistance is difficult to develop in the case of antibacterial action. ${ }^{15}$ Based on the long-term use of silver ions as a dressing. Nanomaterials less than 100nm-nanometer silver are developed to optimize silver ions for the Nano-treatment of silver ions. Moreover, nano-silver has highly optimized physical, biological, and chemical properties. ${ }^{16}$ Reportedly, nanosilver dressings have more advantages in diabetic foot therapy (see Table 1). Once the necrotic tissue is dissolved, wound negative pressure drainage technology can efficiently drain the liquid, reducing the wound healing time and accelerating the growth of granulation tissue which is conducive to diabetic foot treatment. ${ }^{9,17}$

\section{Nanosilver}

Silver nanomaterials in three dimensions with at least a one dimension smaller than $100 \mathrm{~nm}$ are referred to as nano-silver. It is a novel antibacterial product developed using nanotechnology that has stable physical and chemical characteristics. Nano-silver products have good antibacterial effects and a larger contact area with bacteria, which increases the antibacterial efficacy and safety. Besides, drug resistance is less likely. ${ }^{18} \mathrm{Li}$ et al investigated the antibacterial effects of nano- silver through practical tests nearly 40 years ago and proved that the silver activated carbon has purification and bactericidal effects. $^{19}$

\section{The Treatment Principle of Nano-Sliver}

Nano-silver has been shown to act on bacterial cell membrane.

Nano-silver can be deposited around the cell membrane, causing specific cytotoxicity. It reduces cell attachment morphology, weakening the integrity of cell membrane structure, causing properties to change and, eventually cell death. ${ }^{20,21}$ Reportedly, nano-silver can induce the production of reactive oxygen, ${ }^{22}$ which is one of the key mechanisms of nano-silver antibacterial inhibition. Activated oxygen is a byproduct of cell metabolism, and an abnormal accumulation of it can induce an oxidative stress response, causing DNA damage and apoptotic death. Nano-silver is genetically toxic, as it breaks down DNA and eventually induces apoptosis death in pathogenic cells. $^{22}$ On the one hand, nanometer silver can adsorb the cell membrane and cause a stress reaction. ${ }^{22}$ On the other hand, it breaks the cell membrane to inhibit dehydrogenase activity and destroy the respiratory chain. The cytotoxicity of nano-silver, and the destruction of the respiratory chain, can induce the accumulation of active oxygen. ${ }^{23}$ Consequently, it attacks the cell membrane and blocks the cell transmission system. ${ }^{24}$ Besides, nano-silver can also block DNA replication. ${ }^{21}$ Moreover, nano-silver can cause the wrinkle of free DNA morphology in the bacterial cytoplasm, leading to a loss of genetic information transmission and other functions. Additionally, nano-silver can lead to DNA damage and can has a good bacteriostatic effect. ${ }^{24-26}$ Furthermore, nano-silver destroys the cell structure composition and kills bacterial cells by chemically reacting with intracellular substances-NH, -COOH. ${ }^{27}$ Nano-silver can also bind to cell membrane proteins and the respiratory chain, impacting ATP production and consumption in the bacteria, resulting in the death of bacteria. ${ }^{28}$ Reportedly, silver ions can inactivate the mercapto group with the protein. ${ }^{25}$ Nano-silver can also destroy the cell walls by affecting the bacterial living environment. ${ }^{25}$ On the basis of antibacterial, nano-silver also has a certain function of promoting the regeneration of epithelial cells, and the function of minimizing scar formation after healing. ${ }^{29}$ Especially in a local wound test using AgNPs solution at a concentration of $1.8 \mathrm{mg} / \mathrm{mL}$, the wound healed in less than 25 days, ${ }^{30}$ proving that nano-silver can improve the proliferation and repair of damaged epithelium in diabetic foot patients. Diabetes patients generally have lower extremity neuropathy and venous vascular disease. For the above formation mechanism, nano-silver can promote regeneration 
Table I Comparison of Nanosilver Dressings and Other Materials for the Treatment of Diabetic Foot

\begin{tabular}{|c|c|c|c|c|c|c|}
\hline $\begin{array}{l}\text { Document } \\
\text { Years }\end{array}$ & Country & Comparison the Dressings & Nanosilver Advantages & Conclusion & $\begin{array}{l}\text { Separate } \\
\text { Application/ } \\
\text { Joint } \\
\text { Application }\end{array}$ & References \\
\hline 2013 & China & Sterile defat gauze & $\begin{array}{l}\text { Nano-silver combines on the } \\
\text { dressing, makes contact with the } \\
\text { wound, and penetrates into the } \\
\text { subcutaneous tissue due to its } \\
\text { molecular properties. Afterward, } \\
\text { it quickly kills the pathogenic } \\
\text { bacteria. As a Consequently, the } \\
\text { final recovery rate is increased } \\
\text { to varying degrees, and its silver } \\
\text { ions also induces pain-relieving } \\
\text { characteristics. }\end{array}$ & $\begin{array}{l}\text { Has sterile skim gauze curative } \\
\text { effects. The treatment effect is } \\
\text { ordinary, and simply treats local } \\
\text { tissue ulcer; however, nano- } \\
\text { silver dressing is beneficial on } \\
\text { the basis of optimization. It } \\
\text { greatly improves its cure rate, } \\
\text { efficacy, and pain relief. However, } \\
\text { there are limitations. In terms of } \\
\text { single use cost, nano silver price } \\
\text { relatively expensive, with } \\
\text { penetration in local hospitals. }\end{array}$ & Use it alone & [33] \\
\hline 2011 & The UK & $\begin{array}{l}\text { DACC(dialkyl aminformyl } \\
\text { chloride, a fatty acid } \\
\text { derivative) wrapped in } \\
\text { antibacterial dressings }\end{array}$ & $\begin{array}{l}\text { DACC performs well in creating } \\
\text { a biological barrier, manages } \\
\text { bacterial loads, effective for } \\
\text { chronic wounds. Nano-silver, on } \\
\text { the other hand, accelerates } \\
\text { healing and can be used on acute } \\
\text { wounds. }\end{array}$ & $\begin{array}{l}\text { It is used based on the course of } \\
\text { disease. If it is a long-term } \\
\text { chronic disease, the DACC } \\
\text { package dressing could be } \\
\text { prioritized for treatment. } \\
\text { However, for acute, heavy } \\
\text { patients, the treatment of nano- } \\
\text { silver dressing can be given } \\
\text { prioritized. }\end{array}$ & Use it alone & {$[34,38]$} \\
\hline 2021 & China & Regular Vaseline dressing & $\begin{array}{l}\text { Nano-silver dressing decreases } \\
\text { the infection rate, the number of } \\
\text { drug changes, and the healing } \\
\text { time, which accelerates the } \\
\text { conversion rate. }\end{array}$ & $\begin{array}{l}\text { Vaseline dressing is suitable in } \\
\text { the treatment of diabetic foot. } \\
\text { Firstly, the use of Vaseline } \\
\text { dressing mainly prevents foreign } \\
\text { pathogens from invading the } \\
\text { wound; it has limited } \\
\text { antibacterial ability. Experiments } \\
\text { comparing Nano-silver dressing } \\
\text { to Vaseline dressing can be used } \\
\text { to further study the antibacterial } \\
\text { characteristics of nano-silver in } \\
\text { terms of infection rate, changing } \\
\text { times, healing time, and efficacy } \\
\text { of improving optimization. }\end{array}$ & Use it alone & {$[34,4 I]$} \\
\hline 2015 & India & $\begin{array}{l}\text { Microbiology to Polyvinyl } \\
\text { Alcohol (PVA) and } \\
\text { Melyanformaldehyde (MFR) } \\
\text { Resins as Film and Coating } \\
\text { Silver Nano Composites }\end{array}$ & $\begin{array}{l}\text { Microorganisms are effectively } \\
\text { removed by the formation of } \\
\text { PVA-MFR-Ag composites, } \\
\text { particularly after foot infection. } \\
\text { Especially treated nano-silver } \\
\text { dressings improve their stability } \\
\text { based on their bactericidal } \\
\text { performance, without decreasing } \\
\text { the antibacterial activity over } \\
\text { time. }\end{array}$ & $\begin{array}{l}\text { The PVA-MFR-Ag complex was } \\
\text { made on the basis of nano silver } \\
\text { dressing to strengthen the } \\
\text { applicability of nano-silver } \\
\text { dressings. Its stable chemical } \\
\text { coating can prolong the } \\
\text { antibacterial activity of nano- } \\
\text { silver dressing, extend the use } \\
\text { time of nano silver dressing, } \\
\text { reduce the number of nano - } \\
\text { silver dressing replacements, } \\
\text { reduced usage costs, and further } \\
\text { optimize diabetic foot treatment. }\end{array}$ & Joint use & {$[4 I]$} \\
\hline
\end{tabular}

(Continued) 
Table I (Continued).

\begin{tabular}{|c|c|c|c|c|c|c|}
\hline $\begin{array}{l}\text { Document } \\
\text { Years }\end{array}$ & Country & Comparison the Dressings & Nanosilver Advantages & Conclusion & $\begin{array}{l}\text { Separate } \\
\text { Application/ } \\
\text { Joint } \\
\text { Application }\end{array}$ & References \\
\hline 2013 & $\begin{array}{l}\text { South } \\
\text { Korea }\end{array}$ & $\begin{array}{l}\text { Nanocrystalline silver, silver } \\
\text { carboxymethyl cellulose silver, } \\
\text { Sulfampyrimidine silver, } \\
\text { Sulfampyridine, lodine iodide }\end{array}$ & $\begin{array}{l}\text { The healing degree of patients in } \\
\text { various groups has improved to } \\
\text { different degrees. The dressing } \\
\text { effect with nanocrystals is more } \\
\text { effective. }\end{array}$ & $\begin{array}{l}\text { Based on the determination of } \\
\text { the action of silver ion dressings, } \\
\text { additional compound products } \\
\text { of silver also have a certain cure } \\
\text { rate. However, in the } \\
\text { comparative effect of many } \\
\text { experiments, the nano-silver } \\
\text { dressing exhibits better } \\
\text { performance. Nano-silver } \\
\text { optimizes the treatment effect } \\
\text { from the aspects of wound } \\
\text { change, epithelial degree, } \\
\text { granulation formation degree, } \\
\text { level of necrosis, wound biopsy, } \\
\text { and so on to improve the degree } \\
\text { of cure. }\end{array}$ & Use it alone & [42] \\
\hline 2020 & Ireland & The fixed dressing & $\begin{array}{l}\text { Nanosilver gel is safe and } \\
\text { effective. It works better and } \\
\text { reacts faster than other } \\
\text { dressings, and alleviates pain } \\
\text { during cleaning and debridement. }\end{array}$ & $\begin{array}{l}\text { In diabetic foot ulcers, } \\
\text { nanocrystals silver dressings are } \\
\text { better than double the } \\
\text { prescribed dressing, with a good } \\
\text { cure rate, pain -relieving effects. } \\
\text { It reduces costs of replacing the } \\
\text { dressing as well as the use of } \\
\text { painkillers. }\end{array}$ & Use it alone & [35] \\
\hline 2013 & Sri Lanka & General dressings & $\begin{array}{l}\text { The experimental group of nano- } \\
\text { silver gel dressing performed } \\
\text { significantly better than the } \\
\text { conventional dressing group in } \\
\text { terms of pain reduction, } \\
\text { accessory reduction, and } \\
\text { hospitalization time. }\end{array}$ & $\begin{array}{l}\text { Compared with normal } \\
\text { dressings, using nano-silver } \\
\text { dressing reduces the pain, the } \\
\text { number of replacement dressing } \\
\text { is reduced, the treatment rate is } \\
\text { increased, and the length of } \\
\text { hospitalization is also shortened. } \\
\text { It can be inferred that nano- } \\
\text { silver dressings can also save } \\
\text { economy, manpower, and space } \\
\text { cost on the basis of improving } \\
\text { the individual treatment plans, } \\
\text { etc. }\end{array}$ & Use it alone & [38] \\
\hline 2016 & $\begin{array}{l}\text { (China, } \\
\text { India) } \\
\text { British } \\
\text { Journal }\end{array}$ & $\begin{array}{l}\text { Honeysuckle Water Lift } \\
\text { Green Synthetic Silver } \\
\text { Nanoparticles (AgN Ps) }\end{array}$ & $\begin{array}{l}\text { AgN Ps have significant anti- } \\
\text { diabetic activity on diabetic key } \\
\text { enzymes. Green synthetic } \\
\text { nanoparticles are safer than } \\
\text { chemical synthesis. }\end{array}$ & $\begin{array}{l}\text { Nanosilver ions still have certain } \\
\text { toxicological effects. Adopting } \\
\text { green synthetic nanoparticles is } \\
\text { safer in the treatment of diabetic } \\
\text { foot because they retain their } \\
\text { antibacterial effects. }\end{array}$ & Use it alone & [39] \\
\hline
\end{tabular}

(Continued) 
Table I (Continued).

\begin{tabular}{|c|c|c|c|c|c|c|}
\hline $\begin{array}{l}\text { Document } \\
\text { Years }\end{array}$ & Country & Comparison the Dressings & Nanosilver Advantages & Conclusion & $\begin{array}{l}\text { Separate } \\
\text { Application/ } \\
\text { Joint } \\
\text { Application }\end{array}$ & References \\
\hline 2016 & India & Silver Nanoparticles & $\begin{array}{l}\text { Nanosilver particles are more } \\
\text { effective antibacterial agents than } \\
\text { commonly used antibacterial } \\
\text { agents. }\end{array}$ & $\begin{array}{l}\text { Silver nanoparticles have the } \\
\text { greatest inhibitory effect on } \\
\text { MDR strains and E. coli. } \\
\text { Therefore, the antibacterial } \\
\text { effect is more specific to the } \\
\text { patient's foot. However, if the } \\
\text { colonies of the patient foot are } \\
\text { not infected by the above- } \\
\text { mentioned conventional } \\
\text { bacteria, the treatment plan } \\
\text { should be defined based on the } \\
\text { pathological biopsy. }\end{array}$ & Ununited & [40] \\
\hline 2016 & $\begin{array}{l}\text { Australia/ } \\
\text { China }\end{array}$ & $\begin{array}{l}\mathrm{Ag}^{+} \text {ions and nanometer silver } \\
\text { particles (different particle } \\
\text { sizes) }\end{array}$ & $\begin{array}{l}\text { The antibacterial activity of } \\
\text { nanoparticles is associated with } \\
\text { the amount of } \mathrm{Ag}(+) \text { released. } \\
\text { Nanoparticles have stronger } \\
\text { antibacterial activity in a certain } \\
\text { range (specific values are } \\
\text { disputed), which can be based on } \\
\text { the balance of production cost } \\
\text { and production process, and } \\
\text { improves treatment success rate } \\
\text { of diabetic foot while reducing } \\
\text { the production cost. }\end{array}$ & $\begin{array}{l}\text { Nano-silver ion produces more } \\
\text { targeted dressing types for } \\
\text { patients with bacterial infections } \\
\text { and acute diabetic foot. Nano- } \\
\text { silver dressings can improve } \\
\text { treatment efficacy and assist } \\
\text { clinicians in achieving } \\
\text { individualized diabetic foot } \\
\text { treatment by effectively } \\
\text { controlling economic costs. }\end{array}$ & Ununited & {$[39,44]$} \\
\hline 2021 & China & $\begin{array}{l}\text { Epidermal growth factor } \\
\text { combined with nano-silver } \\
\text { dressing, growth factor alone, } \\
\text { nano-silver alone and control } \\
\text { group (conventional surgical } \\
\text { debridement) }\end{array}$ & $\begin{array}{l}\text { Nano silver dressing in joint } \\
\text { epidermal growth factor, } \\
\text { through the relevant } \\
\text { experiments, and found that } \\
\text { nano silver dressing with growth } \\
\text { factor therapy, compared with } \\
\text { the growth of a single factor } \\
\text { dressings, nano silver dressing } \\
\text { and common surgical } \\
\text { debridement, alone by bacterial } \\
\text { culture results can be seen that } \\
\text { the joint group has more } \\
\text { significant bacteriostatic effect. } \\
\text { and can effectively inhibit the } \\
\text { growth of bacteria at the end of } \\
\text { the body. It can also promote } \\
\text { epidermal growth and } \\
\text { granulation tissue formation, } \\
\text { making wound healing effectively. }\end{array}$ & $\begin{array}{l}\text { The combination therapy of } \\
\text { nano-silver growth factor can } \\
\text { promote the growth of } \\
\text { granulation tissue and fiber } \\
\text { tissue through bacteriostasis, } \\
\text { and thus effectively promote } \\
\text { wound healing. Nano-silver } \\
\text { dressing can effectively inhibit } \\
\text { the growth of bacteria through } \\
\text { its silver ions, and then when } \\
\text { combined with growth factors, it } \\
\text { can make up for insufficient local } \\
\text { growth factors to a certain } \\
\text { extent, promote epidermal } \\
\text { growth, form granulation tissue, } \\
\text { shorten the time of wound } \\
\text { healing, and improve the healing } \\
\text { effect. }\end{array}$ & Joint use & [45] \\
\hline
\end{tabular}

through an antibacterial effect and is less resistant to antibiotic treatment than simple antibiotic treatment. In addition, the peptides, nucleic acids, antibiotics, and some of its unique substances and functions (antioxidant-containing polymers, natural nanostructured hydrogels, and nanofiber re- epithelialization, etc.) provided by silver nanoparticles have accelerated wound healing. ${ }^{31}$ The key and main thing in the treatment process of nano-silver dressing is the antibacterial effect of silver ion, coupled with its regenerative healing effect, nano-silver dressing is accurate and efficient in treating 
diabetic foot. Therefore, nano-silver treatment of diabetic foot is a comprehensive process(see Figure 1).

\section{Advantages and Application of Nanosilver Dressings}

Nano-silver has been widely used in surgery, gynecology, gynecology, dermatology, stomatology, medical devices, medical textile protective articles, and contraception. ${ }^{16}$ The application of nano-silver in treating diabetic foot is also becoming more popular in clinical settings. Because Silver ions have anti-infection characteristics, nano-silver dressings suitable for treating diabetic foot patients. It are released slowly and effectively, and the negative charge on the surface of the bacteria destroys its structure, but more scientific experiments are needed to confirm this. ${ }^{32}$ Nano-silver can effectively enhance clinical symptoms, control infection, reduce ulcer area, reduce the number of changes, reduce amputation rate, promote patient wound healing, shorten hospitalization time, and reduce the economic burden of diabetic foot patients.

The efficacy comparison of different materials and nanosilver dressings is shown in Table 1 . The advantages and improvements of nano-silver dressings were observed through the treatment effect of the patients. When comparing the efficacy of nano-silver dressings with skim cotton, betadine, and regular vaseline dressing, it can be seen that the nano- silver dressing group exhibits better outcomes with regards to group dressing cure rate, and the number of recovered patients improved significantly. Besides, the cure rate is higher than that of skim cotton and Vaseline, and nano-silver dressings have a faster healing time, better antibacterial performance, and reduces pain to some extent. ${ }^{33-36}$ However, there are certain limitations to the use of nano-silver ions. The nano product of silver ions is nano-silver. Nano-silver has greater effectiveness and safety when compared to silver ions. However, it still has a certain toxicological effect, particularly on some human organs that are prone to chronic diseases. ${ }^{37}$ Preferential nano-silver dressing is used for treatment in acute and critically ill patients, without regard for its long-term impact. However, some diabetic foot patients who require long-term treatment can consider controlling the condition with less toxic dressings, such as DACC. ${ }^{38}$ Alternatively, using synthetic therapy with nano-silver dressing helps in the chemical synthesis of nano-silver. Plant-based synthesis methods can also be considered, Honeysuckle Water Lift Green synthetic silver nanoparticles (AgN Ps) can also treat diabetic foot through their action on key enzymes. It exhibits better safety performance than chemical synthesis. ${ }^{39}$ Nano-silver dressing plays a significant role in the treatment of diabetic foot secondary infections. Nano-silver dressings kill bacteria more effectively than traditional dressings due to the presence

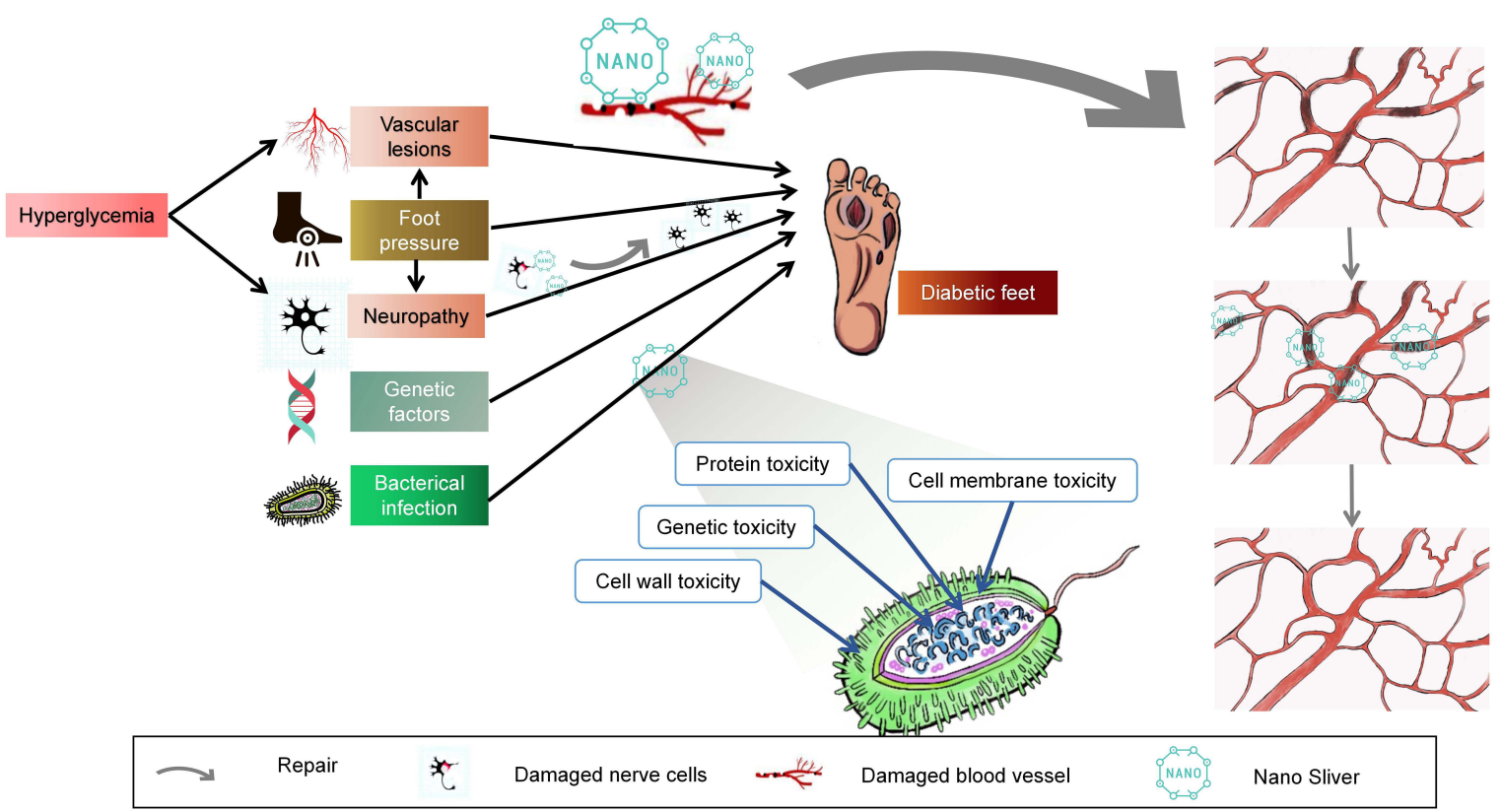

Figure I Nano silver treatment of diabetic foot. 
of silver ions. ${ }^{40}$ The nano-silver dressing is the first choice when there is no clear indication of the type of diabetic foot infection bacteria type and in the emergency treatment of trauma. The silver nanocomposite of microbes on polyvinyl alcohol (PVA) and melamine formaldehyde (MFR) resins as thin film and coating improve the bactericidal action time of the dressing, ${ }^{41}$ which further improves the anti-infection efficiency of nano-silver excipients. To determine the advantages brought by the nanoproducts of silver over the original effectiveness of the silver ions, Nanocrystalline silver and silver carboxymethyl cellulose silver, Sulfonadrimine Silver, Silfonazine, and Control iodide are beneficial. ${ }^{42}$ Multiple comparative experiments using nanosilver ions of different particle sizes have been conducted to further study nanoparticles of silver particles, Silver ions, and for different species. ${ }^{43,44}$ It can be inferred that the therapeutic effect of nano-silver is the effect of silver ions. However, nanoproducts work better than other silver compounds, probably due to their form and size. Comparing the antibacterial effects of the identical E. coli with different nano diameters demonstrate that the nanoparticles are influenced by their morphology and size. Different groups of experiments show that when comparing the same particle size with different strains, the nano-silver particle size has a certain association with its antibacterial capacity. However, the exact values are still somewhat controversial, and the degree of correlation also needs to be further discussed. It is worth mentioning that, on the basis of the treatment with nano-silver dressing, the combination of epidermal growth factor and nano-silver can further promote epidermal growth on the basis of bacteriostasis, compensate for the deficiency of local growth factor, cause granulation tissue grow, and improve the healing efficiency and treatment effect. ${ }^{45}$ On the study of the effects of epidermal growth factor, related studies have shown that cells, growth factors, matrix around on the structure and function of interaction, the mutual influence between them on the cell growth recovery plays a certain, activation of EGFR regulate integrin activation and cell adhesion, create an environment of control promote cell growth, and further help cell recovery. ${ }^{46}$ Preliminary evidence suggests that nano silver dressing, when compared to other dressings in the treatment of diabetic foot, has superiority and uniqueness, especially some of the use of combination therapy, can effectively shorten the treatment time, promote wound healing, and improve the treatment effect, but on the way of the treatment, there are some limitations, specific design need to follow the principle of individualized treatment, the analysis dependent on the specific situation.

\section{Application Prospect of Nanosilver Dressing}

When compared to other antibacterial dressings, nanosilver has remarkable characteristics and advantages when treating diabetic foot, including broad-spectrum effect, wide and safe application, and long post-treatment action time. Empirical studies have shown that nanometer silver reduces pain, as well as the probability of time and infection, in diabetic foot patients. Moreover, if widely developed, nano-silver dressing popularization can also reduce the economic burden on patients, minimize unnecessary pain, enhance the patient survival, and play a specific role in treating high-risk diabetic foot patients. In addition to improving income of diabetic foot patients, nano-silver dressing plays a role in improving the efficacy in other trauma fields. Considering the increasing number of diabetes patients in China, nano-silver dressings should be promoted and developed. However, research on nanosilver dressing needs to expanded; for instance, future studies could examine the harm of nano-silver dressings to aquatic life and the toxic effects on the human body. ${ }^{16,47}$ Reportedly, green synthetic nanoparticles replacing nanoparticles can be adopted as a substitute for chemical synthetic nano-silver particles. It can enhance the safety performance of nanoparticles. ${ }^{39}$ Thus, it can be proved that nano-silver dressings have huge potential in the market of diabetic foot dressings. Appropriate utilization and development of nano-silver materials combined with continued research can improve the performance of nanosilver in terms of to its physical, chemical, and biological aspects, thereby providing better medical conditions to the majority of diabetic foot patients.

\section{Conclusion}

Nano-silver dressings are a novel form of long-spectrum, safe, antibacterial dressing. Its plays a significant role in the prevention and treatment of diabetes. In addition to protecting the wound, facilitating better drainage, and improving safe broad-spectrum anti-infection role, related studies show that its application in the treatment of diabetic foot holds significant advantages, particularly several comparative experiments with different dressings have shown that nano-silver dressings effectively improve the cure rate, the safety of diabetic foot patients, and alleviates pain to a certain level. Effectively improving nano-silver dressing in terms of the limitations of using nano-silver 
dressing and the method of use can provide crucial benefits to diabetic foot patients in many aspects.

\section{Statement of Ethics}

This article does not contain any studies with human or animals performed by any of the authors.

\section{Acknowledgments}

In the process of this article, we are especially grateful to Weihao Li, who has gained a lot of unexpected content in the our mind collision, and his company and support in the writing process. And We are very grateful to Mr. Shen Haitao for his guidance in the illustration part of the article. Finally, we are especially grateful to China Medical University for giving us such a study opportunities and platforms allow us to explore the unknown on the shoulders of giants. Huijing Lin and ALayi BoLatai are co-first authors for this study.

\section{Author Contributions}

Huijing Lin, ALayi BoLatai collected material and wrote the manuscript. $\mathrm{Na} \mathrm{Wu}$ helped with the discussion, supervised the work and provided critical feedback. All authors made substantial contributions to conception and design. Especially ALayi BoLatai wrote the original draft and drew the image about theme. Huijing Lin collected data related to the content and made table $\mathrm{Na} \mathrm{Wu}$ provided direction of research, provided main argument on the content, and designed the structure of the paper. All authors made a significant contribution to the work reported, whether that is in the conception, study design, execution, acquisition of data, analysis and interpretation, or in all these areas; took part in drafting, revising or critically reviewing the article; gave final approval of the version to be published; have agreed on the journal to which the article has been submitted; and agree to be accountable for all aspects of the work.

\section{Funding}

This research was supported by the National Natural Science Foundation of China (No.81700706), the 345 Talent Project of Shengjing hospital, the Clinical research project of Liaoning Diabetes Medical Nutrition Prevention Society (No.LNSTNBYXYYFZXH-RS01B), the Science Foundation of Liaoning Education Department (No. LK201603), and the Virtual simulation experiment teaching project of China Medical University (No.2020-47).

\section{Disclosure}

The authors declare no conflicts of interest in this work.

\section{References}

1. Yazdanpanah L, Nasiri M, Adarvishi S. Literature review on the management of diabetic foot ulcer. World J Diabetes. 2015;6 (01):37-53. doi:10.4239/wjd.v6.i1.37

2. Chinese Medical Association Diabetes Branch, Chinese Medical Association Infectious Diseases Branch, Chinese Medical Association Tissue Repair and Regeneration Branch. Chinese diabetic foot prevention guidelines (2019 Edition) (I). Chin J Diabetes. 2019;11(2):92-108.

3. Chen WL, Ma HM. The application status of nano-silver dressings in wound care. Nurs Res. 2020;2020:1034-1037.

4. Andrews KL, Houdek MT, Kiemele LJ. Wound management of chronic diabetic foot ulcers: from the basics to regenerative medicine. Prosthet Orthot Int. 2015;39(1):29-39. doi:10.1177/ 0309364614534296

5. Güneş A, Ceylan A, Sarioglu Y, et al. Reactive oxygen species mediate abnormal contractile response to sympathetic nerve stimulation and noradrenaline in the vas deferens of chronically diabetic rats: effects of in vivo treatment with antioxidants. Fundam Clin Pharmacol. 2005;19 (1):73-79. doi:10.1111/j.1472-8206.2004.00312.x

6. Charanya G, Mothiram Patil K, Thomas VJ, et al. Standing foot pressure image analysis for variations in foot sole soft tissue properties and levels of diabetic neuropathy. ITBM-RBM. 2004;25 (1):23-33. doi:10.1016/j.rbmret.2003.11.002

7. Liu JQ. Progress in the pathogenesis and treatment of diabetic foot. J Difficult Difficult Dis. 2007;006(006):375-377.

8. Wang XC, Wang B, Zou Q. Application of new dressings based on the theory of "wet healing" in the treatment of diabetic foot ulcer wounds. Adv Modern Biomed. 2007;2007(08):1228-1229.

9. Gu YQ. Guidelines for diagnosis and treatment of diabetic foot in China. Chin J Clin. 2020;48(01):19-27.

10. Sun YZ, Zhang ZH, Ma J, et al. Research On Secondary Suture Promoting Diabetic Foot Ulcers Healing under Guidance of Huchang Theory. Chin J Integrat Surg. 2015;21(06):560-562.

11. Hou SY. Efficacy and infection treatment of anisodamine combined with gentamicin for topical diabetic foot. Foot Health Care. 2018;27 (16):89-90.

12. Qu YY, Xie CH, Ju SZ, et al. Experimental study on antibacterial activity of MEBO. Chin J Burn Trauma Select Select. 1998;1998 (04):15-17.

13. Radji M, Putri CS, Fauziyah S. Antibiotic therapy for diabetic foot infections in a tertiary care hospital in Jakarta, Indonesia. Diabetes Metabol Syndr Clin Res Rev. 2014;8(4):221-224. doi:10.1016/j. dsx.2014.09.006

14. Omar NS, El-Nahas MR, Gray J. Novel antibiotics for the management of diabetic foot infections. Int $J$ Antimicrob Agents. 2008;31 (5):411-419. doi:10.1016/j.jjantimicag.2007.10.016

15. Su TL, Shi LQ, Li WR, et al. Observation on the effect of silver ion dressing on infected wounds. J Guiyang Med Coll. 2010;35 (04):390-391.

16. Chen X, Schluesener HJ. Nanosilver: a nanoproduct in medical application. Toxicol Lett. 2008;176(1):1-12. doi:10.1016/j. toxlet.2007.10.004

17. Liu S, He C, Cai Y, et al. Evaluation of negative-pressure wound therapy for patients with diabetic foot ulcers: systematic review and meta-analysis. Ther Clin Risk Manag. 2017;13:533-544. doi:10.2147/TCRM.S131193

18. Lu L. Nano-Silver Synthesis and Its Antibacterial Mechanism. Soochow University; 2015.

19. Li YH, Xie RZ, Zhao DB, et al. The bactericidal effect of silver-loaded activated carbon and its application in water treatment. Sichuan Forest Sci Technol. 1980;1980(04):61-66. 
20. Sondi I, Salopek-Sondi B. Silver nanoparticles as antimicrobial agent: a case study on E. coli as a model for Gram-negative bacteria. J Colloid Interf Sci. 2004;275(1):177-182. doi:10.1016/j. jcis.2004.02.012

21. Chen FF, Chen FY, Wang YY, et al. Research progress on sterilization mechanism and application of nano-silver. J Anhui Agric Sci. 2016;44(09):28-30.

22. Kim S, Ryu D. Silver nanoparticle-induced oxidative stress, genotoxicity and apoptosis in cultured cells and animal tissues. $J \mathrm{Appl}$ Toxicol. 2013;33(2):78-89. doi:10.1002/jat.2792

23. You CG, Han CM, Wang XG, et al. The progress of silver nanoparticles in the antibacterial mechanism, clinical application and cytotoxicity. Mol Biol Rep. 2012;39(9):9193-9201. doi:10.1007/ s11033-012-1792-8

24. Liu X, Ren Y, Zhou ZJ, et al. Research progress on antibacterial mechanism and application of nano-silver. J Anhui Agric Univ. 2017;17(4):702-708.

25. Wu ZS, Hu HY, Ren Y, et al. Research progress on antibacterial mechanism of nano-silver. Prog Chem Industr. 2015;2015 (005):1349-1356, 1370.

26. Feng QL, Wu J, Chen GQ, et al. A mechanistic study of the antibacterial effect of silver ions on Escherichia coli and Staphylococcus aureus. J Biomed Mater Res. 2000;52(4):662-668. doi:10.1002/10974636(20001215)52:4<662::AID-JBM10>3.0.CO;2-3

27. Cheng DC, Yang J, Zhao YL. The application of nano-silver antibacterial materials in medical appliances and daily necessities. Med Health Equip. 2004;25(011):27-30.

28. Lok CN, Ho CM, Chen R, et al. Proteomic analysis of the mode of antibacterial action of silver nanoparticles. J Proteome Res. 2006;5 (4):916-924. doi:10.1021/pr0504079

29. Ju F. The effect of skin wound inorganic induction active dressing combined with nano-silver medical antibacterial dressing in the treatment of elderly patients with diabetic foot chronic ulcer. Chin J Gerontol. 2015;035(017):4987-4988.

30. Almonaci Hernández CA, Juarez-Moreno K, Castañeda-Juarez ME, et al. Silver nanoparticles for the rapid healing of diabetic foot ulcers. Int J Med Nano Res. 2017;4(019): 2378-3664.

31. Ezhilarasu H, Vishalli D, Dheen ST, et al. Nanoparticle-based therapeutic approach for diabetic wound healing. Nanomaterials (Basel). 2020;10(6):1234. doi:10.3390/nano10061234

32. Huang CH, Wang RQ, Yan ZR. Silver dressing in the treatment of diabetic foot. A protocol for systematic review and meta-analysis. Medicine. 2021;100(07):e24876.

33. Li H. The application of nano-silver medical antibacterial dressing in diabetic foot care. Chin J Nosocomiol. 2013;2013(05):1162.
34. Yang L, Liu F, Chen Y, et al. Research on the treatment of diabetic foot with ulcer based on nano-silver antibacterial dressing. J Nanosci Nanotechnol. 2021;21(2):1220-1229. doi:10.1166/jnn.2021.18680

35. Singh B, Kapoor S, Gupta AK. Comparing the efficacy of nano crystalline silver dressing versus betadine dressing in management of diabetic foot ulcer. Int Surg J. 2020;7(5):1424. doi:10.18203/23492902.isj20201568

36. Ramanaiah NV, Saikrishna S, Chandrasekhar C, et al. A clinical study on efficacy of nanocrystalline silver dressing in diabetic foot ulcers. $J$ Evid Based Med Healthc. 2015;2(45):8160-8170. doi:10.18410/jebmh/2015/1097

37. Shi $\mathrm{C}, \mathrm{Xu}$ LM, Shao AL. Current status of toxicological research on nano-silver. J Pharm Anal. 2013;2013(12):2025-2033.

38. Haycocks S, Chadwick P, Guttormsen K. Use of a DACC-coated antimicrobial dressing in people with diabetes and a history of foot ulceration. Wounds Uk. 2011;07(1):108-114.

39. Balan K, Qing AW, Wang AY, et al. Antidiabetic activity of silver nanoparticles from green synthesis using Lonicera japonica leaf extract. RSC Adv. 2016;6:40162-40168. doi:10.1039/C5RA24391B

40. Anitha M, Divya G, Monisha DM, et al. A comparative study of conventional antibiotic sensitivity testing against silver nanoparticles among diabetic foot ulcer patients. Int J Chem Pharm Anal. 2016;03 (03):1-7.

41. Kakkar R, Madgula K, Nehru Y, et al. Polyvinyl alcohol-melamine formaldehyde films and coatings with silver nano particles as wound dressings in diabetic foot disease. Eur Chem Bull. 2015;04 (2):98-105.

42. Lee JH, Kwak JJ, Shin HB, et al. Comparative efficacy of silver-containing dressing materials for treating MRSA-infected wounds in rats with streptozotocin-induced diabetes. Wounds a Compendium Clin Res Pract. 2013;25(12):345-354.

43. Sotiriou GA, Pratsinis SE. Antibacterial activity of nanosilver ions and particles. Environ Sci Technol. 2010;44(14):5649-5654. doi:10.1021/es101072s

44. Wang Y, Wang Y, Cheng Y, et al. The relationship between nano-silver particle size and antibacterial properties. China Leather. 2016;45(005):1-4.

45. Zhang KH, Li Y, He J, et al. Therapeutic effect of epidermal growth factor combined with nano silver dressing on diabetic foot patients. Front Pharmacol. 2021;12: 627098.

46. Rao TC, Ma VP, Blanchard A, et al. EGFR activation attenuates the mechanical threshold for integrin tension and focal adhesion formation. J Cell Sci. 2020;133(13):jcs238840.

47. Wang ZY, Zhao J, Li N, et al. Research progress on the toxic effects of artificial nanoparticles on aquatic organisms and their mechanisms. Environ Sci. 2010;2010(06):1409-1418.

\section{Publish your work in this journal}

Diabetes, Metabolic Syndrome and Obesity: Targets and Therapy is an international, peer-reviewed open-access journal committed to the rapid publication of the latest laboratory and clinical findings in the fields of diabetes, metabolic syndrome and obesity research. Original research, review, case reports, hypothesis formation, expert opinion and commentaries are all considered for publication. The manuscript management system is completely online and includes a very quick and fair peer-review system, which is all easy to use. Visit http://www.dovepress.com/testimonials.php to read real quotes from published authors. 